\title{
PENGARUH KEPERCAYAAN MEREK TERHADAP KEPUTUSAN KONSUMEN MEMBELI PRODUK HANDPHONE VIVO DI KALANGAN MAHASISWA S1 UNIVERSITAS TADULAKO
}

\author{
Anindya Puteri \\ Maskuri Sutomo \\ Rahmat Mubaraq \\ Program Studi S1 Manajemen Fakultas Ekonomi Universitas Tadulako \\ Email: Anindyaaputry@gmail.com
}

\begin{abstract}
The purpose of this study is to know and analyze the influence of brand trust on purchasing decisions. The variables of this research are brand characteristics $(X 1)$, company characteristics $(X 2)$ and brand consumer characteristics (X3). While the dependent variable is Purchase Decision (Y). The research method used is descriptive method causal with the number of samples 88 people with purposive sampling techniques and methods of analysis, Multiple Linear Regression with the help of computer programs SPSS for windows, Release 25.0. The result of research shows that there is influence of brand trust consist of characteristic of brand, characteristic of company and characteristic of consumer brand to consumer decision to buy vivo handphone product among student of tadulako University 11 simultantly or partially
\end{abstract}

Keywords: characteristics of the brand, corporate characteristics, brand consumer characteristics, purchase decision.

\begin{abstract}
ABSTRAK
Tujuan penelitian ini adalah untuk mengetahui dan menganalisis pengaruh kepercayaan merek terhadap keputusan pembelian. Variabel penelitian ini yaitu karakteristik merek $\left(\mathrm{X}_{1}\right)$, karakteristik perusahaan $\left(\mathrm{X}_{2}\right)$ dan karakteristik konsumen merek $\left(\mathrm{X}_{3}\right)$. Sedangkan variabel dependen yaitu Keputusan Pembelian (Y). Metode penelitian yang digunakan adalah metode deskriptif kausal dengan jumlah sampel 88 orang dengan teknik purposive sampling dan Metode analisis, Regresi Linear Berganda dengan bantuan program komputer SPSS for windows, Release 25.0. Hasil penelitian menunjukan bahwa terdapat pengaruh Kepercayaan merek terdiri dari Karakteristik merek, Karakteristik perusahaan dan Karakteristik konsumen merek terhadap keputusan konsumen membeli produk handphone vivo dikalangan mahasiswa S1 Universitas tadulako secara simultan maupun parsial.
\end{abstract}

Kata Kunci: karakteristik merek, karakteristik perusahaan, karakteristik konsumen merek, keputusan konsumen.

\section{PENDAHULUAN}

Perkembangan dan kemajuan teknologi yang semakin menglobal membawa dampak pada dunia usaha. Adanya perkembangan dan kemajuan teknologi, dunia usaha dituntut untuk selalu bersaing dalam hal peningkatan mutu produk barang dan jasa. Salah satu kemajuan teknologi adalah bidang komunikasi yang diciptakan untuk memudahkan system komunikasi bagi masyarakat.Meningkatnya kebutuhan masyarakat akan sarana komunikasi menjadikan alat komunikasi sebagai sesuatu yang sangat penting dalam kehidupan sehari-hari.

Tuntutan akan kebutuhan informasi yang sangat cepat dan mudah membuat para produsen yang bergerak dalam bidang komunikasi melakukan inovasi baru. Menciptakan alat komunikasi yang praktis, salah satunya yaitu menciptakan telepon seluler (ponsel) atau yang lebuh dikenal dengan istilah handphone. Telepon seluler atau handphone sebagai alat komunikasi, tetapi fitur tambahan serta desain produk juga menjadi dasar pertimbangan dalam meutuskan memilih jenis atau merek produk. Sebagian kelompok masyarakat Indonesia menggangap bahwa handphone yang dimiliki menunjukan status pemiliknya, handphone yang baru dan yang mahal menunjukan status ekonomi yang mapan dan trendi. Namun sebagian lainya ada yang berpandangan bahwa handphone adalah alat komunikasi. Maka bentuk fitur, serta jasa lainya melengkapi produk tidak menjadi perhatian masyarakat tersebut 
Puteri, A.

bahkan perkembangan teknologi produk tidak menjadikan masyarakat tersebut tergiur bahkan mereka banyak yang menggunakan handphone tipe lama sepanjang fungsinya sebagai alat komunikasi masih tetap berfungsi.

Adapun tujuan yang ingin dicapai dalam penelitian ini adalah:

1. Untuk mengetahui variabel pengaruh Kepercayaan merek yang terdiri dari karakteristik merek, Karakteristik perusahaan, dan Karakteristik konsumen merek terhadap keputusan konsumen membeli produk handphone Vivo dikalangan mahasiswa S1 Universitas tadulako.

2. Untuk mengetahui variabel karakteristik merek mempengaruhi keputusan konsumen membeli produk handphone Vivo dikalangan mahasiswa S1 Universitas tadulako.

3. Untuk mengetahui variabel Karakteristik perusahaan mempengaruhi keputusan konsumen membeli produk handphone Vivo dikalangan mahasiswa S1 Universitas tadulako.

4. Untuk mengetahui variabel Karakteristik konsumen merek mempengaruhi keputusan konsumen membeli produk handphone Vivo dikalangan mahasiswa S1 Universitas tadulako.

\section{KAJIAN LITERATURE DAN PENGEMBAGAN HIPOTESIS Pengertian Kepercayaan merek}

Pratiwi dan Saino (2014) menyatakan kepercayaan merek adalah rasa aman yang dimiliki oleh seorang konsumen melalui interaksinya dengan merek yang didasarkan pada persepsi konsumen bahwa merek tersebut dapat dipercaya dan bertanggung jawab untuk kepentingan dan kesejahteraan konsumen.

\section{Model Lima Tahap Proses Pembelian Konsumen}

Model lima tahap menurut Kotler \& Keller (2009:185) antara lain sebagai berikut:

1. Pengenalan Masalah

Proses pembelian dimulai saat pembeli mengenali sebuah masalah atau kebutuhan. Kebutuhan tersebut dapat ditimbulkan oleh rangsangan internal atau eksternal. Pemasar perlu mengidentifikasi keadaan yang memicu kebutuhan tertentu. Mengumpulkan informasi dari sejumlah konsumen, pemasar dapat mengidentifikasi rangsangan yang paling sering membangkitkan minat akan suatu produk. Pemasar kemudian dapat mengembangkan strategi yang memicu minat konsumen.

2. Pencarian Informasi

Konsumen yang tergugah oleh kebutuhanya akan terdorong untuk mencari informasi yang lebih banyak. Kita dapat membaginya kedalam dua tingkat. Situasi pencarian informasi yang lebih ringan dinamakan perhatian yang menguat. Pada tingkat selanjutnya, orang hanya menjadi lebih peka terhadap informasi tentang produk. Pada tingkat selanjutnya, orang itu mungkin memastikan pencarian aktif informasi dengan mencari bahan bacaan, menelpon teman atau mengunjungi toko untuk mempelajari produk.

3. Evaluasi Alternatif

Beberapa konsep dasar akan membantu kita memahami proses evaluasi konsumen. Pertama konsumen berusaha untuk memenuhi suatu kebutuhan. Kedua konsumen mencari manfaat tertentu dari solusi produk. Konsumen memandang masing-masing produk sebagai sekumpulan atribut dengan kemampuan yang berbeda-beda dalam memberikan manfaat yang digunakan untuk memuaskan kebutuhan tersebut. Konsumen mengembangkan sekumpulan keyakinan atas suatu merek yang membentuk citra merek,

4. Keputusan Pembelian

Pada tahap evaluasi, konsumen membentuk preferensi atas merek-merek dalam kumpulan pilihan. Konsumen mungkin membentuk niat untuk membeli produk yang paling disukai. Terdapat dua faktor yang mempengaruhi niat pembelian dan keputusan membeli, yaitu:

1) Faktor sikap orang lain

Sejauh mana sikap orang lain mengurangi sikap alternatif yang disukai seseorang bergantung pada dua hal:

(1) Intensitas sikap negatif orang lain terhadap alternatif yang disukai konsumen.

(2) Motivasi konsumen untuk menuruti keinginan orang lain 
2) Faktor situasi yang tidak terantisipasi

Faktor ini dapat muncul dan mengubah niat pembelian. Jadi, preferensi dan bahkan niat pembelian bukanlah perkiraan perilaku pembelian yang benar-benar handal.

5. Perilaku pasca Pembelian

Setelah memilih suatu produk, konsumen akan mengalami level kepuasan atau ketidakpuasan tertentu. Tugas pemasar tidak berakhir pada suatu produk dibeli, melainkan berlanjut hingga periode pasca pembelian. Pemasar harus memantau kepuasan pasca pembelian tindakan pasca pembelian dan pemakaian produk pasca pembelian.

\section{Kerangka Pemikiran}

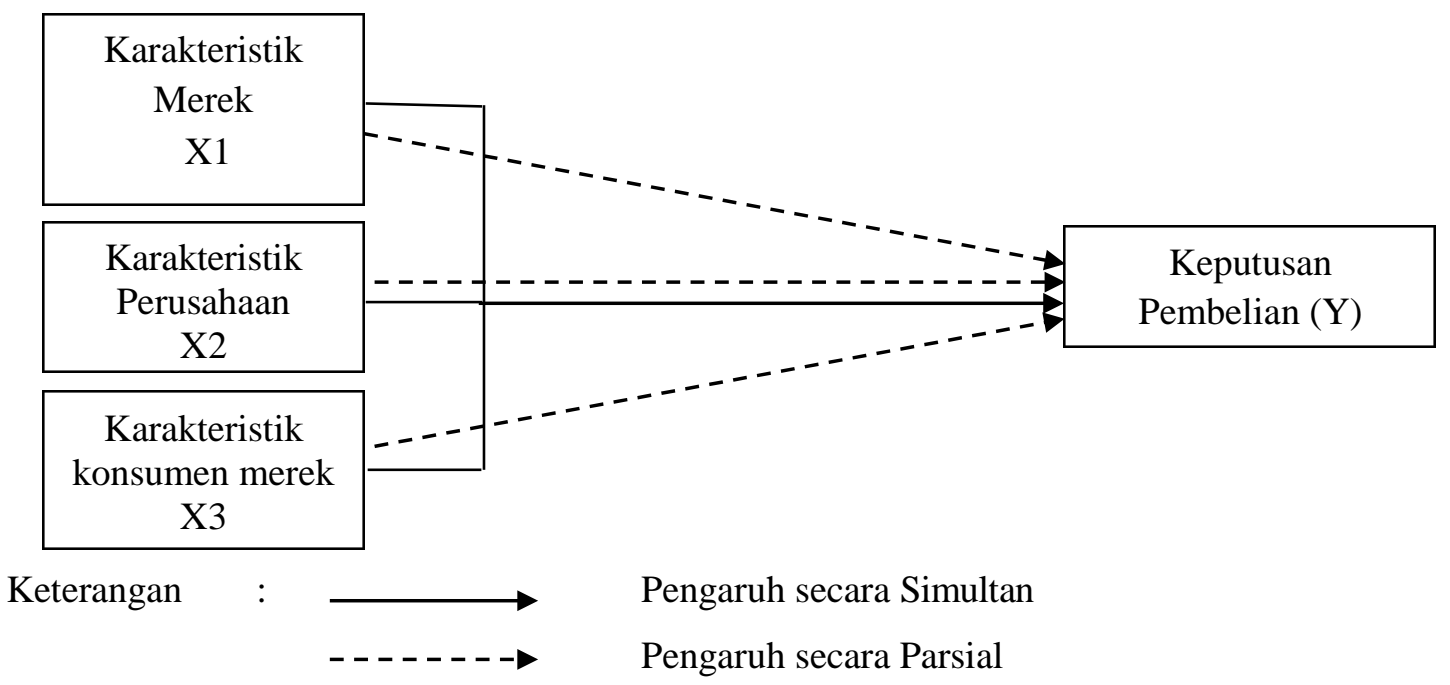

Gambar 1. Kerangka Pemikiran

\section{Hipotesis}

Hipotesis penelitian adalah dugaan sementara mengenai dua variabel atau lebih mengenai hasil penelitian, selanjutnya hipotesis penelitian ini dirumuskan sebagai berikut:

1. Kepercayaan merek yang terdiri dari Karakteristik merek, Karakteristik perusahaan, Karakteristik konsumen merek secara serempak berpengaruh signifikan terhadap keputusan konsumen membeli produk handphone Vivo dikalangan mahasiswa S1 Universitas tadulako.

2. Karakteristik merek berpengaruh signifikan terhadap keputusan konsumen membeli produk handphone vivo dikalangan mahasiswa S1 Universitas tadulako.

3. Karakteristik perusahaan berpengaruh signifikan terhadap keputusan konsumen membeli produk handphone Vivo dikalangan mahasiswa S1 Universitas tadulako.

4. Karakteristik konsumen merek berpengaruh signifikan terhadap keputusan konsumen membeli produk handphone Vivo dikalangan mahasiswa S1 Universitas tadulako.

\section{METODE PENELITIAN}

Jenis penelitian yang digunakan adalah deskriptif-kausal dan desain penelitian ini adalah deskriptif kausal, oleh karena penelitian ini berusaha menjabarkan hasil-hasil penelitian dari pengaruh variabel independen (X), yaitu karakteristik merek, karakteristik perusahaan, karakteristik konsumen merek terhadap variabel $(\mathrm{Y})$, yaitu keputusan konsumen membeli produk handphone vivo dikalangan mahasiswa S1 Universitas tadulako. Berdasarkan pertimbangan tersebut peneliti menetapkan jumlah sampel dengan ketentuan $22(3+1)$ variabel yaitu 88 responden.

Teknik penarikan sampel yang digunakan dalam penelitian ini, yaitu Purposive Sampling. Menurut Sugiyono (2009:85) Purposive Sampling adalah teknik penarikan sampel dengan pertimbangan tertentu. Adapun kriteria responden yang dijadikan sampel pada penelitian ini adalah sebagai berikut:

1. Bersedia mengisi kuisioner dan diwawancarai 
Puteri, A.

2. Dapat memberikan tanggapan secara objektif

3. Pengguna handphone merek Vivo

4. Mahasiswa S1 Universitas tadulako

Sebelum data dikumpulkan dan diolah, maka peneliti perlu melakukan uji coba instrumen terlebih dahulu guna mengetahui tingkat validitas dan reliabilitas suatu instrumen.

1. Uji Validitas

Ghozali (2013:52) uji validitas adalah sejauh mana kehandalan sebuah alat ukur dalam mengukur apa yang diukur. Instrument yang valid berarti alat ukur yang digunakan mendapatkan data. Syarat minimum untuk dianggap memenuhi syarat adalah $r=0,3$. Jadi, kolerasi antara butiran dengan skor total kurang dari 0,3 maka butir dalam instrument tersebut dinyatakan tidak valid. Sebaliknya, jika skor total positif dan lebih besar $0,3(r>0,3)$ maka instrument tersebut dinyatakan valid.

2. Uji Reliabilitas

Uji relibilitas dilakukan terhadap penyataan-penyataan yang sudah valid, guna mengetahui sejauh mana hasil pengukuran tetap konsisten bila dilakukan pengukuran kembali terhadap gejala yang sama. Pengujian ini, peneliti mengukur reliabelnya suatu variabel dengan melihat Crowbach Alfha dengan signifikan yang digunakan lebih besar dari 0.70 . Suatu konstruk atau variabel dikatakan relibel jika nilai cronbach Alfa $>0.70$ Ghozali (2013:47-48).

Metode analisis data menggunakan analisis regresi linier berganda. Analisis regresi linier Berganda digunakan Untuk mengetahui ada tidaknya pengaruh Kepercayaan merek terhadap keputusan konsumen membeli produk handphone Vivo dikalangan mahasiswa S1 Universitas tadulako, maka digunakan alat uji statistik yaitu regresi linier berganda yang dapat dirumuskan ( Sugiyono, 2014: 262):

$$
\mathrm{Y}=\mathrm{a}+\mathrm{b}_{1} \mathrm{X}_{1}+\mathrm{b}_{2}+\mathrm{X}_{2}+\ldots \ldots \ldots \ldots \mathrm{b}_{\mathrm{n}} \mathrm{X}_{\mathrm{n}}+\mathrm{e}
$$

Bila formulasi metematis Regresi Liner Berganda tersebut diaplikasikan dalam penelitian ini, maka akan diperoleh bentuk persamaan sebagai berikut:

$$
Y=b_{1} X_{1}+b_{2} X_{2}+b_{3} X_{3}+e
$$

Dimana :

$$
\begin{aligned}
& \mathrm{Y}=\text { Keputusan konsumen } \\
& \mathrm{b}_{1}=\text { Koefisien regresi variabel } \mathrm{X}_{1} \text { (Karakteristik Merek) } \\
& \mathrm{b}_{2}=\text { Koefisien regresi variabel } \mathrm{X}_{2} \text { (Karakteristik Perusahaan) } \\
& \mathrm{b}_{3}=\text { Koefisien regresi variabel } \mathrm{X}_{3} \text { (Karakteristik Konsumen Merek) } \\
& \mathrm{X}_{1}=\text { Karakteristik Merek } \\
& \mathrm{X}_{2}=\text { Karakteristik Perusahaan } \\
& \mathrm{X}_{3}=\text { Karakteristik Konsumen Merek } \\
& \mathrm{e} \quad=\text { error / variabel pengganggu }
\end{aligned}
$$

\section{HASIL DAN PEMBAHASAN}

\section{Hasil Uji Analisis Regresi Linear Berganda}

Penelitian ini menggunakan analisis regresi linear berganda dengan tujuan untuk menguji pengaruh iklan televisi dan citra merek terhadap keputusan pembelian. Untuk lebih jelasnya hasil analisis regresi linear berganda dapat dilihat pada tabel 1 berikut: 
Tabel 1. Hasil Uji Analisis Regresi Linear Berganda

\begin{tabular}{|c|c|c|c|c|c|}
\hline \multicolumn{6}{|c|}{ Dependen Variabel Y = Keputusan konsumen } \\
\hline \multirow{2}{*}{$\begin{array}{c}\text { Variabel } \\
\text { Independen }\end{array}$} & \multicolumn{2}{|c|}{$\begin{array}{c}\text { Unstandardized } \\
\text { Coefficients }\end{array}$} & \multirow{2}{*}{$\begin{array}{c}\begin{array}{c}\text { Standardized } \\
\text { Coefficients }\end{array} \\
\text { Beta }\end{array}$} & \multirow[t]{2}{*}{$\mathrm{T}$} & \multirow[t]{2}{*}{$\operatorname{sig}$} \\
\hline & B & Std. Error & & & \\
\hline (Constant) & $-0,413$ & 0,322 & & $-1,280$ & 0,204 \\
\hline $\begin{array}{c}\text { Karakteristik } \\
\text { merek } \\
\left(\mathrm{X}_{1}\right) \\
\end{array}$ & 0,370 & 0,083 & 0,351 & 4,478 & 0,000 \\
\hline $\begin{array}{c}\text { Karakteristik } \\
\text { perusahaan } \\
\left(\mathrm{X}_{2}\right)\end{array}$ & 0,194 & 0,076 & 0,191 & 2,550 & 0,013 \\
\hline Citra Produk $\left(\mathrm{X}_{3}\right)$ & 0,493 & 0,088 & 0,440 & 5,569 & 0,000 \\
\hline Multiple R & $=0,811^{\mathrm{a}}$ & \multicolumn{2}{|c|}{ Sig. $F=0,000$} & & \\
\hline Adjusted R Square & $=0,657$ & \multicolumn{3}{|c|}{$=0,05$ tingkat kepercayaan $95 \%$} & \\
\hline
\end{tabular}

\section{Sumber: Data diolah Tahun 2018}

Berdasarkan tabel 1 di atas, dapat di tulis dalam bentuk persamaan regresi linear berganda. Lebih jelasnya bentuk persamaan tersebut dapat dilihat sebagai berikut:

$$
Y=(-0,413)+0,370 X_{1}+0,194 X_{2}+0,493 X_{3}+e
$$

1. Nilai Konstanta sebesar $-0,413$, artinya jika variabel (Kepercayaan merek) bernilai 0, maka variabel dependen (keputusan konsumen membeli produk handphone Vivo dikalangan mahasiswa S1 Universitas tadulako) nilainya sebesar $-0,413$ Setiap ada kenaikan pada variabel independen sebesar satu satuan maka akan meningkatkan variabel dependen sebesar nilai koefisiensi beta masing-masing variabel independen yang dikalikan dengan besarnya kenaikan yang terjadi.

2. Koefisien regresi dimensi Karakteristik merek sebesar 0,370, artinya jika Karakteristik merek naik satu satuan, maka keputusan konsumen membeli produk handphone Vivo dikalangan mahasiswa S1 Universitas tadulako naik sebesar 0,370.

3. Koefisien regresi dimensi Karakteristik perusahaan sebesar 0,194, artinya jika Karakteristik perusahaan naik satu satuan, maka keputusan konsumen membeli produk handphone Vivo dikalangan mahasiswa S1 Universitas tadulako naik sebesar 0,194.

4. Koefisien regresi dimensi Karakteristik konsumen merek sebesar 0,493, artinya jika Karakteristik konsumen merek naik satu satuan, maka keputusan konsumen membeli produk handphone Vivo dikalangan mahasiswa S1 Universitas tadulako naik sebesar 0,493.

\section{Hasil Pengujian Hipotesis}

\section{Hasil Pengujian Hipotesis Secara Simultan (Uji F)}

Tahap selanjutnya adalah menguji signifikan hubungan atau uji $\mathrm{F}$ antara variabel Karakteristik merek $\left(\mathrm{X}_{1}\right)$ Karakteristik perusahaan $\left(\mathrm{X}_{2}\right)$ Karakteristik konsumen merek (X3) terhadap keputusan konsumen (Y) dengan perhitungan menggunakan SPSS 25 dengan hasil sebagai berikut: 
Puteri, A.

Tabel 2. Hasil Uji F(Simultan)

\begin{tabular}{|l|r|r|r|r|r|}
\hline Model & Sum of Squares & Df & Mean Square & F & Sig. \\
\hline $1 \quad$ Regression & 18,912 & 3 & 6,304 & 53,620 &, $000^{\mathbf{b}}$ \\
Residual & 9,876 & 84 &, 118 & & \\
Total & 28,788 & 87 & & & \\
\hline
\end{tabular}

Sumber: Data diolah Tahun 2018

Berdasarkan tabel 2, diperoleh angka signifikan sebesar 0,000. angka $0,000<0,05$ oleh karena itu, hipotesis diterima. Hal ini berarti terdapat pengaruh secara simultan pada variabel Kepercayaan merek yang terdiri dari Karakteristik merek, Karakteristik perusahaan, dan Karakteristik konsumen merek terhadap keputusan konsumen membeli produk handphone Vivo dikalangan mahasiswa S1 Universitas tadulako.

\section{Hasil Pengujian Hipotesis Secara parsial (Uji t)}

Pengujian hipotesis secara parsial adalah untuk mengetahui apakah variabel Karakteristik merek, Karakteristik perusahaan dan Karakteristik konsumen merek secara parsial berpengaruh secara positif dan signifikan terhadap keputusan konsumen membeli produk handphone Vivo dikalangan mahasiswa S1 Universitas tadulako. Adapun hasil pengujian secara parsial untuk setiap variabel independen terhadap variabel dependen dapat dilihat dari penjelasan berikut :

1. Karakteristik merek

Berdasarkan tabel 3, hasil pengujian SPSS diperoleh hasil angka signifikan sebesar 0,000. Angka $0,000<0,05$ oleh karena itu, hipotesis diterima. Hal ini berarti terdapat pengaruh variabel Karakteristik merek terhadap keputusan konsumen membeli produk handphone Vivo dikalangan mahasiswa S1 Universitas tadulako.

2. Karakteristik perusahaan

Berdasarkan tabel 3, hasil pengujian SPSS diperoleh hasil angka signifikan sebesar 0,000. Angka $0,000<0,05$ oleh karena itu, hipotesis diterima. Hal ini berarti terdapat pengaruh variabel Karakteristik perusahaan terhadap keputusan konsumen membeli produk handphone Vivo dikalangan mahasiswa S1 Universitas tadulako.

3. Karakteristik konsumen merek

Berdasarkan tabel 3, hasil pengujian SPSS diperoleh hasil angka signifikan sebesar 0,000. Angka $0,000<0,05$ oleh karena itu, hipotesis diterima. Hal ini berarti terdapat pengaruh variabel Karakteristik konsumen merek terhadap keputusan konsumen membeli produk handphone Vivo dikalangan mahasiswa S1 Universitas tadulako.

\section{Pembahasan atau Hasil Analisis}

\section{Karakteristik merek}

Hasil pengujian hipotesis penelitian, ditemukan bahwa variabel Karakteristik Merek berpengaruh terhadap keputusan konsumen membeli Produk Handphone merek Vivo di kalangan mahasiswa S1 Universitas Tadulako. Temuan ini diartikan apabila Karakteristik Merek mengalami peningkatan maka proses keputusan pembelian juga akan mengalami peningkatan. Karakteristik merek mempunyai peran yang sangat penting dalam menentukan pengambilan keputusan konsumen untuk mempercayai suatu merek. Hal ini disebabkan oleh konsumen melakukan penilaian sebelum membeli.

Penelitian yang dilakukan pada Konsumen membeli produk handphone merek vivo di kalangan mahasiswa S1 Universitas Tadulako, pada indikator persepsi terhadap merek merupakan indikator dominan yang di pilih oleh responden, hal ini mengindikasikan bahwa dengan berkualitasnya suatu produk maka akan meningkat pula persepsi baik seseorang terhadap suatu merek, yang nantinya akan berdampak pada keputusan pembelian. 


\section{Karakteristik perusahaan}

Hasil pengujian hipotesis penelitian, ditemukan bahwa variabel Karakteristik Perusahaan berpengaruh terhadap keputusan konsumen membeli Produk Handphone merek Vivo di kalangan mahasiswa S1 Universitas Tadulako. Temuan ini diartikan apabila Karakteristik Perusahaan yang baik maka proses keputusan pembelian juga akan mengalami peningkatan. Karakteristik perusahaan yang ada di balik suatu merek juga dapat mempengaruhi tingkat kepercayaan konsumen terhadap merek tersebut. Pengetahuan konsumen tentang perusahaan yang ada di balik merek suatu produk merupakan dasar awal pemahaman konsumen terhadap merek suatu produk.

Penelitian yang dilakukan pada konsumen membeli produk handphone merek vivo di kalangan mahasiswa S1 Universitas Tadulako, pada indikator Integritas Perusahaan merupakan indikator dominan yang di pilih oleh responden, hal ini di karenakan produk yang dibuat oleh perusahaan mempunyai hasil yang baik, sehingga produk yang baik itu mencerminkan rasa kepercayaan konsumen akan produk-produk yang di hasilkan perusahaan Vivo.

\section{Karakteristik konsumen merek}

Hasil pengujian hipotesis penelitian, ditemukan bahwa variabel Karakteristik Konsumen Merek berpengaruh terhadap keputusan konsumen membeli Produk Handphone merek Vivo di kalangan mahasiswa S1 Universitas Tadulako. Temuan ini diartikan apabila Karakteristik Konsumen Merek mengalami peningkatan maka proses keputusan pembelian juga akan mengalami peningkatan. Karakteristik konsumen merek merupakan dua kelompok yang saling mempengaruhi. Oleh sebab itu, karakteristik merek-konsumen dapat mempengaruhi kepercayaan merek. Karakteristik ini meliputi kemiripan antara konsep emosional konsumen dengan kepribadian merek, kesukaan terhadap merek dan pengalaman terhadap merek.

Penelitian yang dilakukan pada Konsumen membeli produk handphone merek vivo di kalangan mahasiswa S1 Universitas Tadulako, pada indikator Kepribadian Merek merupakan indikator dominan yang di pilih oleh responden, hal ini di karenakan fitur-fitur yang terdapat pada handphone merek Vivo mudah untuk di pakai semua kalangan, seperti remaja, dewasa, dan orang tua sehingga handphone merek Vivo cocok untuk kebutuhan keluarga.

\section{PENUTUP}

\section{Kesimpulan}

Berdasarkan hasil penelitian yang telah dijabarkan, maka diperoleh kesimpulan:

1. Karakteristik merek, Karakteristik perusahaan, dan Karakteristik konsumen merek secara simultan berpengaruh signifikan terhadap keputusan konsumen membeli produk handphone Vivo dikalangan mahasiswa S1 Universitas tadulako

2. Karakteristik perusahaan secara parsial berpengaruh signifikan terhadap keputusan konsumen membeli produk handphone Vivo dikalangan mahasiswa S1 Universitas tadulako.

3. Karakteristik konsumen merek secara parsial berpengaruh signifikan terhadap keputusan konsumen membeli produk handphone Vivo dikalangan mahasiswa S1 Universitas tadulako

\section{Saran}

1. Penciptaan brand characteristics berpengaruh pada Keputusan Konsumen. Maka dengan adanya hal tersebut reputasi merek perusahaan Vivo lebih diperhatikan dengan melakukan peningkatan kualitas produk, sehingga Vivo semakin mendapat kepercayaan konsumen.

2. Penciptaan company characteristics berpengaruh pada keputusan konsumen. Maka nama baik perusahaan akan semakin diperhatikan agar konsumen lebih menaruh kepercayaan terhadap perusahaan Vivo bahwa perusahaan Vivo adalah perusahaan yang baik dengan cara selalu memberikan pelayanan yang maksimal kepada setiap konsumen dalam hal service maupun melayani keluhan konsumen.

3. Penciptaan pengalaman merek berpengaruh pada Keputusan Konsumen. Maka dengan adanya hal tersebut pengalaman merek konsumen Vivo lebih diperhatikan dengan melakukan peningkatan promosi, sehingga Vivo semakin mendapat kepercayaan konsumen. 
Puteri, A.

\section{REFERENSI}

Ghozali, Imam. (2013). Aplikasi Analisis Multivariate dengan program IBM SPSS (kelima). Semarang: Universitas Diponegoro.

Juari, Rohmad. (2010). Pengaruh Kepercayaan Merek pada Pembentukan Loyalitas Merek Apple di Yogyakarta. Vol.1, No.1, Februari 2010| JBTI.

Kotler, Philip. (2002). Manajemen Pemasaran: Jilid 1. Edisi Milenium. Jakarta: Prehallindo.

Kotler, Philip dan Kevin Lane Keller (2009). Manajemen Pemasaran (Edisi Kedua Belas) Jakarta: Cetakan Ketiga, PT. Indeks.

Pratiwi dan Saino (2014). Pengaruh Kepercayaan Merek dan Kesan Kualitas terhadap Keputusan Pembelian Ulang. Jurnal Ilmu Manajemen, Volume 2, Nomor 4, Oktober 2014.

Sugiyono. (2014). Statistika untuk Penelitian. Bandung: Alfabeta. 